\title{
IHOR SKYBA,
}

Volyn Orthodox Theological Academy (Lutsk, Ukraine)

e-mail: prorector@vpba.org, ORCID 0000-0003-0331-184

\section{THE PLACE AND PART OF POLIKARP (SYKORSKYI) IN THE SPREAD AND STRENGTHENING OF THE MOVEMENT FOR THE UKRAINIZATION OF THE ORTHODOX CHURCH IN POLAND IN THE $1920^{\text {th }}$}

The dynamics of changes in the spiritual-ecclesiastical and religious dimensions of Ukraine over the last quarter of a century testifies to a clear tendency towards self-determination and institutionalisation of the Orthodox community. The first half of the twentieth century became one of the stages of the movement for the creation of the Ukrainian Orthodox Church. A special place in the mentioned events had the figure of Metropolitan Polikarp (Sikorskyi). In 1922, a former associate of the Kyiv Spiritual Consistory and the Ministry of Religions of the Government of the Ukrainian People's Republic, Petro Sikorskyi, found himself in Western Volyn, a part of the Second PolishLithuanian Commonwealth. After his tonsure, Polikarp (Sykorskyi) headed the Derman monastery, and soon afterwards - the Miletsky monastery. At Miletsky Monastery, the hieromonk Polikarp used every opportunity he could to Ukrainize the life of the monastic community. At the beginning of 1923 Polikarp (Sikorskyi) was a Dean of the monasteries of the Volyn Diocese. It was important for Polikarp (Sikorskyi) to participate in the work of the Volyn Diocesan Congress of 1923, where he presided. The decisions of congress provided a formal basis for the Ukrainianization of church services. Delegates voted for the return of the Ukrainian language to divine service and the preparation of liturgical texts in Ukrainian. In the first half of 1923 Archimandrite Polikarp (Sikorskyi) was already a rector of the Zagayat Monastery. Here he focused, among other things, on the de-Russification of the divine services and the whole rhythm of the brethren's spiritual life. Polish police closely followed the archimandrite and claimed that Sikorskiy had turned the monastery into a hotbed of Ukrainian agitation. Not only the Polish police concerned itself with Archimandrite Polikarp (Sikorskiy's) views on the matters of religion and statehood. The representatives of the Russian ecclesiastical and political circles did, too. In October of 1923 by the respective decree, the head of the Church transferred P. Sikorskiy to Vilnius. The intensification of Ukraine's movement for the national and religious independence led to the appointment of Archimandrite Polikarp (Sikorskyi) to the posts of a rector of the cathedral and a dean of a municipality in Volodymyr in the spring of 1926. At that time, a conflict between the pro-Moscow priests and the Ukrainian community led by Arseni Richinsky intensified in the city. Polikarp (Sikorskyi) managed to satisfy the demands of the Ukrainians, but in early 1927 he was transferred to the Zhyrovichi Monastery. Nevertheless, Archimandrite Polikarp (Sikorskyi) remained one of the leaders and a symbolic figure in Ukraine's movement for the national and religious independence in Volyn. This was also confirmed by the Lutsk Church Congress of 1927 and other events in the life of the Orthodox Church of Poland. The other vector of Archimandrite Polikarp's contacts pointed to the UPR circles. Polikarp (Sikorskyi) maintained a dialogue with the UPR leader in exile, Andriy Livitsky. All these circumstances led to the ordainment of Polikarp (Sikorskyi) to the Bishop of Lutsk in 1932. The paper that follows publishes for the first time the unknown facts and certain aspects of Metropolitan's life, of which our knowledge is limited. The article also analyzes the Metropolitan's contribution to the Ukrainizationo of the Church of Volhynia in the interwar period. The purpose of the study is to investigate the extent of Polikarp (Sikorskiy's) Ukrainianizational activities in Volhynia and his impact on social and religious processes. From this goal, the following tasks arise: to evaluate the contribution of Polikarp (Sikorskiy) to the Ukrainianization of Church and religious life of Orthodox community of Poland in the interwar period; to show the extent of the influence of the bishop's figure on the achievements of the movement for the national and religious independence of Volyn in the interwar period.

Key words: Orthodox Church of Ukraine; Polikarp (Sikorskiy); Diocese of Volyn-Kremenets; Ukrainian Orthodoxy; Ukrainization.

Introduction

Metropolitan Polikarp (Sikorskyi) is a representative of the spiritual, ecclesiastical and civil community of the Kyiv region. Studying in primary and secondary spiritual educational establishments, later on - working in the ecc- lesiastical and administrative institutions of the Kyiv diocese, membership in Ukrainian public institutions determined his spiritual and national-cultural identity. In the 1920s, P. Sikorskyi organically entered the Orthodox Church's life of Western Volhynia within the boundaries of 
interwar Poland. Here he continued his activities aimed at building Ukrainian Orthodoxy. He soon became one of the leaders of the national-religious movement, a potential bishop. The religious and life philosophy of the future bishop was formed among Ukrainian ecclesiastical and political forces who, after the fall of the Russian Empire, became at the forefront of the institutional development of Ukrainian Orthodoxy and the Ukrainian state.

Activity of Polikarp (Sikorskyi) in Volyn in the 1920s was in sight of both domestic (Bidnov, 1921; Doroshenko, 1940; Vlasovsky, 1961; 1977; Savchuk, 1984; Voloshin, 1997; Pashchenko, 1997; Bartholomew (Vashchuk), 2003; Stocklos, 2003) and foreign (Ranevsky, 1948; Heyerb 1953; Berkhof, 2005) scientists. However, the limited use of the source base, the dominance of established narratives prevented a comprehensive and objective study of the role of Polikarp (Sikorskyi) in the spread and strengthening of the movement for Ukrainianization of the Orthodox Church in Volyn in the designated period.

The purpose of the article is to determine, based on archival sources and published documents and materials, the scope of Ukrainianization of Poikarp (Sikorskyi) in Volhynia, his influence on the priorities of Ukraine's movement for the religious and national independence, achievements in the sphere of democratization of the Church.

\section{Methodology}

The methods of analysis, systematization, synthesis, as well as chronological and descriptive methods, are used. Taken together, these methods have become an important mechanism for achieving the goal of exploring the place and role of Polycarp (Sikorsky) in the spread and strengthening of the movement for Ukrainianization of the Orthodox Church of Poland in the 1920s.

\section{Results of the study and their discussion}

In 1922, Peter Sikorsky found himself in Volhynia and decided to be tonsured a monk. At that time, part of the former government and military of the Ukrainian People's Republic was able to settle down in the territory of Volyn Voivodeship and engage in local spiritual, social, cultural, political and economic life.

Petro Sikorskyi managed to establish contacts with Dionysii (Valedynskyi), the governor of the diocese of Volyn within the Second Polish-Lithuanian Commonwealth ${ }^{1}$. Petro Sikorskyi's request to be ordained was dated July 1 , 1922. In his petition he called himself a refugee from Greater Ukraine. "For a long time, I intended - Petro Dmytrovych wrote, - to accept an Inchoic rank in the Kyiv Lavra, but by the will of God, because of the various political events of recent years, I found myself in Volhynia and, without being able to exercise my intention, to adopt monasticism in the Kyiv Lavra, I beg your Honor, the Most Gracious Archpastor and Father, to see me as a monk in one of the monasteries of the diocese entrusted to you"2.

By the decree of the Volyn Spiritual Consistory, Petro

\footnotetext{
1 Лист єпископа Діонисія (Валединського) Володимирській повітовій "Просвіті", 24 лютого 1921 р. Державний архів Волинської області. (Bishop Dionysii (Valedynskyi's) letter to the Prosvita of Volodymyr povit, February $24^{\text {th }} 1921$. Volyn State Archive, Fond 390, List. 1, File 2, P. 32).

2 Прохання Петра Сікорського єпископу Крем'янецькому Діонисієві (Валединському), 1 липня 1922 р. Державний архів Тернопільської області (Petro Sikorskyi request to the Bishop of Kremenets, Dionysii (Valedynskyi), July the $1^{\text {st }}, 1922$. Ternopil State Archive, Fond 148, List 1, File 41, P. 93).
}

Sikorskyi has been appointed a full-time novice to the Dermansky Trinity Monastery ${ }^{3}$. Bishop Dionysii appointed a tonsure and ordination at the end of July. On the twentyseventh of July, Petro Dmytrovych took a monastic vow with the name of Polikarp in the Zagayat monastery.

On the twenty-eighth of July, on the Prince Volodymyr the Great, Equal of the Apostles, Day, Bishop Dionysii (Valedynskyi) ordained the monk Polycarp in a hierodeacon during his service at the Church of St. Joasaph of Zahaietskyi Monastery ${ }^{4}$. The tonsure took place on Sunday, July $30^{\text {th }}$

In August 1922, a collegiate governing body was established for the management of the Derman Monastery, consisting of four persons: Hieromonk Polikarp, who was appointed viceroy of the monastery by the oral consent of Bishop Dionysius; steward of the monastery of Hieromonk Barlaam; the Shi'a treasurer; and Hieromonk Yevtykhii ${ }^{5}$.

Polikarp (Sikrosyi) faithfully fulfilled his duties as he had considerable experience in church and administrative work as the head of the Kyiv Spiritual Consistory. This prompted Oleksii (the Public) in a report dated August $10^{\text {th }}$ to ask Bishop Dionysii to approve of P. Sikorsky as the governor of the monastery, as well as to award him with a golden pectoral cross $^{6}$.

Yet in September of 1922, hieromonk Polikarp (Sikorskyi) was transferred from Derman to the Miletsky Monastery ${ }^{7}$. The previous Rector, hieromonk Theodosius, was relieved of his duties of a leader ${ }^{8}$. Hard work awaited a new abbot in Myltsi: the monastery was in ruins; it was crucial to form a brethren and look for the sources of financial support for the monastery. During the First World War, almost all inhabitants of the Miletsky Monastery were

3 Наказ Волинської духовної консисторії, № 9120, 3 липня 1922 р. Державний архів Тернопільської області (Volyn Spiritual Consistory decree no. 9120 , July the $3^{\text {rd }} 1922$. Ternopil State Archive, Fond 148, List 1, File 41, P. 96).

${ }^{4}$ Допит ставленику монахові Полікарпу (Сікорському) перед висвятою його на ієромонахи, 27 липня 1922 р. Державний архів Тернопільської області (Interrogation of appointee monk Polikarp (Sikorskyi) before his tonsure to be a hieromonk, July $27^{\text {th }}$ 1922. Ternopil State Archive, Fond 148, List 1, File 41, P. 97). ${ }_{5}^{5}$ Рапорт настоятеля Дерманского монастыря, архимандрита Алексия (Громадского) управляющему Волынской епархией епископу Дионисию (Валединскому), №1, 10 августа 1922 г. Державний архів Тернопільської області (Report of the Rector of the Derman monastery, archimandrite Oleksii (the Public), to the leader of Volyn diocese, Dionysii (Valedynskyi), no. 1, August $10^{\text {th }}$ 1922, Ternopil State Archive, Fond 148, List 1, File 41, P. 97). ${ }^{6}$ Указ Священного Синода Православной митрополии в Польше епископу Волынскому и Кременецкому Дионисию (Валединскому), № 43, 30 августа 1922 г. Державний архів Тернопільської області (The Holy Synod Decree of the Orthodox Metropole in Poland to Bishop of Volyn and Kremenets Dionysii (Valedynskyi), no. 43, August $30^{\text {th }}$ 1922. Ternopil State Archive, Fond 148, List 1, File 275, P. 16).

7 Рапорт архиепископа Волынского и Кременецкого Священному Синоду Православной митрополии в Польше, 6 ноября 1922 г. Державний архів Тернопільської області (Archbishop of Volyn and Kremenets to the Holy Synod of the Orthodox Metropole in Poland, November $6^{\text {th }}$ 1922. Ternopil States Archive, Fond 148, List 1, File 41, P. 143).

8 Указ Священного Синода Православной митрополии в Польше архиепископу Волынскому и Кременецкому Дионисию (Валединскому), № 101, 9 сентября 1922 г. Державний архів Тернопільської області (The Decree of the Holy Synod of the Orthodox Metropole in Poland, to the Archbishop of Volyn and Kremenets Dionysii (Valedynskyi), no. 101, September $9^{\text {th }} 1922$. Ternopil State Archive, Fond 148, List 1, File 41, P. 3). 
evacuated to Izium of Kharkiv province (Bartholomew (Vashchuk), 2003: 31). It was not until 1920-1922 that the monks of the monastery returned to Myltsi.

While staying at the Miletsky Monastery, hieromonch Polikarp used every opportunity to Ukrainize the life of the monastic community. The monks guided by the Russian ecclesiastical traditions complained to Archbishop Dionysius of the abbot, who conducted the de-Russification.

Polikarp (Sikorskyi) was able to set straight the spiritual, financial and economic life of the Miletsky Monastery. That he owed to his education, practical knowledge of the church charter, the experience of church-administrative work in the Kyiv region. In early 1923, P. Sikorskyi was mentioned in the documents as a Dean of the monasteries of the Volyn Diocese.

Volyn Diocesan Congress that took place in Kremyanka on May $30^{\text {th }}$ through June $2^{\text {nd }}$ in 1923 , should be considered an attempt to change the ways of the Church. By the order of Metropolitan Dyonisii, archimandrite Polikarp (Sikorskyi) presided on it. The participants of the meeting addressed the matters related to staff, retaining Volyn Theological Consistory and funding of schools and retired clergy ${ }^{9}$.

High inflation rates and post-war devastation prompted congressional delegates to decide to increase parish taxation for the diocesan governing body to be able to sustain itself. For the first time after years of war, payments to church pensioners were restored. A separate line of the budget specified the provision of the activities of the diocesan missionary.

The matter of funding for the functioning of theological schools provoked a heated discussion. In that respect, representatives of the movement for religious and national independence of Ukraine, led by Fr. Nykanor Abramovych, supported the introduction of the Ukrainian language into the educational process starting September 1, 1923. This suggestion was supported by the Congress. This result was also made possible by the support of Archimandrite Polikarp as chairman of the assembly.

The assembly's decisions also provided a formal basis for the Ukrainianization of ministrations. The congress delegates voted for the re-introduction of the Ukrainian language to sacred services and the preparation of liturgical texts in Ukrainian.

Staffing changes in the managerial vertical in the administrative vertical of the Volyn Diocese of the first half of 1923 led to the appointment of Archimandrite Polikarp (Sikorskyi) to the post of a rector of the Zahaietskyi Monastery. The situation in this monastery was more stable. That allowed Fr. Polikarp to focus on the de-Russification of the ministrations and, as such, the whole rhythm of the spiritual life of the fraternity.

The Polish police followed the archimandrite closely, using confidants' delations. Credible sources reported that in the summer of 1923, the police recorded the creation of the Ukrainian coterie by Fr. Polycarp within the monastery. The abbot played host the former UPR representatives, offering them lodgings and food. The police argued that Sikorskyi turned Zahaietskyi Monastery into a hotbed of Ukrainian agitation. Thus, the monastery came under silent surveillance by the Polish police ${ }^{10}$.

\footnotetext{
${ }^{9}$ Єпархіальний з'їзд Волинської єпархії в м. Кремінці 30 травня - 2 червня 1923 р. Додаток до "Релігійно-наукового вісника". 1923. Ч. 11-12. (Diocesan Congress of the Volyn Diocese in Kremyanka, May $30^{\text {th }}$ through June $2^{\text {nd }}, 1923$. Appendix to the Religious Scientific Bulletin. 1923. Issues 11-12)

10 Podanie delegatury ukraińskiej ludnosći prawosławnej z
}

Not only the Polish police concerned itself with Archimandrite Polikarp (Sikorskiy's) views on the matters of religion and statehood. The representatives of the Russian ecclesiastical and political circles, who considered the Orthodox Church in Poland an institutional ground for future resuscitation of the Russian Empire, did, too. Metropolitan Dionysii decided to transfer Archimandrite Polycarp to the Vilnius Church of the Holy Spirit as a result. In October of 1923 by the respective decree, the head of the Church transferred P. Sikorskiy to Vilnius.

In the spring of 1926, Archimandrite Polikarp (Sikorskyi) was appointed to the posts of a rector of the cathedral and a dean of a municipality in Volodymyr. At around that time, a conflict between pro-Moscow priests and the Ukrainian community was exacerbated in the city. The Ukrainian community led by Arsen Richynskyi demanded the Ukrainianization of ministrations. It is also worthy of note that since the First World War, the Ukrainian liberation competitions of 1917-1921 and the first years of the Polish administration, Volodymyr was a city with strong national traditions. One of their manifestations was the Volodymyr Spiritual Board, which for several years led the life of the Orthodox communities of the Volodymyr Vicariate of the Volyn-Zhytomyr Diocese.

The conflict between the pro-Moscow priests and the Ukrainian movement for the religious and national independence of Ukraine intensified in Volodymyr in the summer of 1924 after the death of the rector of the cathedral, Fr. Arsenii Bordiuhovskyi. Father Bordiuhovskyi was at the time the chairman of the Volodymyr Spiritual Board and had a positive attitude towards the de-Russification of ministrations. The leader of the Ukrainian forces was Fr. Petro Tabinskyi. Prior to the arrival of the new rector, he tried to speed up the introduction of the Ukrainian language to the sacred services. Seeking support, Fr. P. Tabinskyi delivered a series of public lectures at Provita Society of Volodymyr, explaining the need for the de-Russification of church life. Another direction of the priest's work was the establishment of cooperation with the doctor Arsen Richynskyi (Ukrainizatsiya..., 1927: 6-8).

Petro Tabinskyi's activities provoked a backlash on part of the clergy and the faithful. The aggravation of the situation made Metropolitan Dionysii intervene. At the end of 1924, on the basis of a detailed study of the reports of the rector of St. Volodymyr Fr. N. Danilevich and the cathedral priest Fr. P. Tabinskyi, he decided not to change the staff of clerics and parishioners and set the order of ministrations in Church-Slavonic and Ukrainian languages: at eight o'clock in the morning the services were in Church Slavonic, and at ten o'clock they were in Ukrainian ${ }^{11}$.

The decision of Metropolitan Dionysii only briefly relieved the tension within the city's Orthodox community ${ }^{12}$. It was necessary to address the issue of the language of

Wołynia d-ra Arsenjusza Reczyńskiego, Platona Domanieckiego, Eugenjusza Petrykowskiego do pana Ministra spraw wewnętrznych 25 grudnia 1926 r. Volyn State Archive, Fond. 46, List 9, File 699, P. 4.

11 Резолюція митрополита Варшавського і Волинського і всієї Польщі Діонисія (Валединського), № 1326, 20 грудня 1924 р. Державний архів Тернопільської області (Resolution of Metropolitan of Warsaw and Volyn and all Poland Dionysii (Valedynskyi), no. 1326, December 20th 1924. Ternopil State Archive, Fond 148, List 5, File 206, P. 11).

12 List otwarty do jego ekscelencji Metropolity Cerkwi Prawoslawnej w Polsce Djonizego. Zycie Wolynia. 1925. № 43(90). 25 pazdziernika. S. 5-6. 
the ministrations in Volodymyr. In April, Archimandrite Polikarp (Sikorskyi) was appointed rector of the city's cathedral. This decision testified the desire of Metropolitan Dionysii to find a way out of a difficult situation. In Volodymyr there was a powerful Ukrainian centre, led by Arsen Richynskyi. There was also a Russian one, in which Yevhen Komarevych took the leading positions.

At the beginning of August 1925, as a commissioner from the Ukrainian community of Volodymyr, Arsen Richynskyi made an appropriate request to Metropolitan Dionysii (Valedinskyi). It said that for two years the city had been fighting for the Ukrainianization of sacred services. Against the movement for the ministrations in Ukrainian, as the publications in the magazines For Freedom and Źycie Wołynia show, functioned a coterie called of supporters of ministrations in Slavic ${ }^{13}$. Arsen Richynskyi claimed that the three commissioners of the said group represented only 29 men and their wives residing on the Gnoeva and Vasilievska streets.

To solve the case, A. Richynskyi suggested that supporters of ministrations in Slavic be provided with the Mykolayiv Church, which is near Hnoeva Street and closer than the cathedral. To introduce in that very temple sacred services in Slavic by one of its parishioners. The proponents of ministrations in Slavic from Vasilevska Street be pointed to the fact that they should stick by their own church and not interfere in the affairs of another parish. Since the peasantry in the suburbs of Fedorovka, Lobachin, Shistov, Zaryachchya, Pomoroki, Ponichiv and Martselivka and all urban population, who upheld the Ukrainian language of sacred services gravitate towards the cathedral and no other temple could fit them - to appoint the cathedral for the sacred services in Ukrainian. That should have applied to both liturgical and vesper's services. Arsen Rychinskyi was convinced that such a solution would not only be fair, but would also bring peace to the ecclesiastical life of Volodymyr.

In August of 1926, Archimandrite Polikarp reported to Metropolitan Dionysius about local ecclesiastical life. First of all, he pointed out that the parish of the cathedral consisted mainly of Ukrainians, peasants from the villages attached to the cathedral. They had a high level of religious consciousness. They required ministrations in Ukrainian. Instead, they were opposed by a small group of burghers, mostly formed by the former Russian government officials, who maintained some influence in the city's self-government. P. Sikorskyi wrote to the Metropolitan who came to Volodymyr on Palm Sunday. Immediately, he was approached by supporters of the Slavic language of ministrations and asked that the church services were held in Slavic ${ }^{14}$. To which P. Sikorskyi replied that the order of Metropolitan Dionysii dated December 21, 1924, on the order of ministrations in the temples of Volodymyr should be obeyed. For further conclusions, Archimandrite Polikarp

\footnotetext{
13 Прохання уповноважених Володимирської парафії митрополиту Варшавському і Волинському і всієї Польщі Діонисію (Валединському), 8 серпня 1926 р. Державний архів Тернопільської області (Commissioners' Request to to the Metropolitan of Warsaw and Volyn and all Poland Dionysii (Valedinskyi), August $8^{\text {th }}, 1926$. Ternopil State Archive, Fond 148, List 5, File 206, P. 31). 14 Рапорт архімандрита Полікарпа (Сікорського) митрополиту Варшавському і Волинському і всієї Польщі Діонисієві (Валединському), ч. 460, 12 серпня 1926 р. Державний архів Тернопільської області (Acrhimandrite Polikarp (Sikorskiy's) Report to the Metropolitan of Warsaw and Volyn and all Poland Dionysii (Valedinskyi), p. 460, August $12^{\text {th }}, 1926$. Ternopil State Archive, Fond 148, List 5, File 206, P. 15)
}

planned to get acquainted with the parish life and the parishioners and find out how many faithful really want the ministrations to be served in Slavic. The same answer was given to the pro-Ukrainian party.

For three months, Polikarp (Sikorskyi) thoroughly studied the state of the matters. This enabled him to draw appropriate conclusions. Thus, the Ukrainian population formed the majority of the faithful of the cathedral's parish in Volodymyr. The Slavic group consisted of a small amount of townspeople, who numbered three dozen. The previous solution to the situation involved early liturgies be served in Slavic by Fr. Sakovskyi with Deacon Luke. The Ukrainians did not feel content with that order of things and they demanded that the morning and evening prayers were said in Ukrainian.

According to Archimandrite Policarp, the solution to the situation in the city would have been to grant permission to perform the services in Ukrainian in the cathedral, and the supporters of the Church-Slavonic be given the Mykolaiv church. In addition, P. Sikorskyi advised that it would have been compulsory for the rector of the cathedral to organize a solemn liturgy in the cathedral on one Sunday, and another one - in the Mykolaiv church. This would allow every parishioner to know their church and to eliminate misunderstandings between the faithful and clergy.

By the respective resolution, Metropolitan Dionysii gave blessing to the transformations suggested by Archimandrite Polikarp. The development of events led to the meeting of members of the parish of Volodymyr cathedral on November 1, 1926 in the presence of Archbishop Polikarp (Sikorskyi), priest Kostiantyn Dombrovskyi, priest Mykola Shyrotskyi, deacon Vasyl Pankevych, acolyte Leonid Pashkevych and acolyte Mykhailo Telezhynskyi. ${ }^{15}$ Abbot of the cathedral Fr. Polycarp informed the congregation about the establishment and settlement of normal relations within the parish in lieu of the ministration, the Divine Services, being held in Ukrainian and Slavic. In order to stabilize the situation, the rector of the cathedral urged members of the parish, and especially priests, not to refuse to serve in all cases. The Archimandrite further asked the audience to comment on this issue. All adherents except Fr.Kostiantyn Dombrovskyi agreed with the rector's view and also stressed that they agreed to serve ministrations in Ukrainian and Slavic. Father Kostiantyn Dombrovskyi refused to serve and preach in Ukrainian since he was ordered by the metropolitan to serve ministration only Slavic and preach in Russian. In addition, the priest stated that he did not speak Ukrainian. As a result, the Assembly took the rector's report into account and pursuance, and the statement of Fr. Kostiantyn Dombrovskyi - into account.

This development concerned the Russians and they made every effort to put Polikarp (Sikorskyi) out of commission in Volodymyr. At the beginning of 1927, Fr. Heorhii Boryshkevych, a protector of the Russians, was appointed a new superior of the cathedral in Volodymyr.

So, the next period of pastoral work of Archimandrite Polikarp (Sikorskyi) became the Zhirovichy Monastery of the Hrodna-Novogrudok Diocese. However, even while in Zhyrovichy Monastery, Archimandrite Polikarp (Sikorskyi) was not only one of the leaders but also a symbol of the movement for religious and national independence of

\footnotetext{
15 Протокол засідання членів причту Володимирського кафедрального собору, 1 листопада 1926 р. Державний архів Тернопільської області (Minutes of the meeting of the members of the parish of Volodymyr cathedral, November $1^{\text {st }} 1926$. Ternopil State Archive, Fond 148, List 5, File 206, P. 32).
} 
Ukraine in Volyn. Among other things, this was confirmed by the Lutsk Church Congress of 1927 and other events in the life of the Orthodox Church of Poland.

Preparation for a church congress in Lutsk showed that Polikarp (Sikorskyi) was considered by many a potential contender for episcopal ordination ${ }^{16}$. As the issue of holding the Lutsk Church Congress was previously discussed in Warsaw with G. Juzzewski and other representatives of the highest echelons of the Polish authorities, the permission to hold it was obtained ${ }^{17}$.

In a situation where preparations for the convention had already begun, the church authorities forbade the Orthodox clergy to participate in it. Thus, any of the decisions that the congress would adopt, would not be legally binding for the bishopric. Metropolitan Dionysii paid special attention to the neutralization of potential candidates for bishops, whose tonsure was lobbied by the movement for the national and religious independence of Ukraine. Polikarp (Sikorskyi) understood the reason for his urgent transfer from Volodymyr. In a letter to Peter the Defender of March 24, 1927, the Archimandrite stated that he was already in Vilnius, where he was trying to do everything possible to advance the Ukrainianization of Orthodoxy in Poland. In particular, he served a memorial service for T. Shevchenko ${ }^{18}$.

The other vector of Archimandrite Polikarp's contacts pointed to the UPR circles. Polikarp (Sikorskyi) maintained a dialogue with the UPR leader in exile, Andriy Livitsky. Thus, archimandrite's being transferred from Volhynia only postponed his ordainment to the Bishop.

To relieve the tension with the Ukrainian national-church movement after the Lutsk church congress, in the fall of 1927 Metropolitan Dionysii gave blessing to the Ukrainian language of ministrations in the Mykolayiv Church of Volodymyr. In October, the church was consecrated by the Protopresbyter of the UPR Army, rector of Lutsk Holy Cross Church, Fr. Pavlo Pashchevskyi.

As a result of the parliamentary elections in Poland of 1928, the deputy of the Diet became I. Vlasowski. He sought to continue ecclesiastical and civic activities. On July 1, 1928, during the meeting of I. Vlasovsky, A. Rychynsky, S. Khrutsky, and other Ukrainian figures with Metropolitan Dionysii, there were already two bishopsUkrainians in the status of vicars for Volyn and Polissia. Rumor had it that the Metropolitan agreed to ordain the Bishops after the vows of Fr. O. Milkov, Fr. P. Tabinski and Fr. M. Bukhovich's tonsures. Archimandrite Polikarp (Sikorskyi) was not mentioned as a candidate for bishops. Later, information about potential ordinations was not confirmed, and Dionysii (Valedinskyi) only confirmed the right of the Ukrainian language to sound in the temples.

After A. Rychynskyi's conflict with Metropolitan Dionysii during the work of the Metropolitan Council, and the subsequent anathema of the movement for the religious and national independence of Ukraine, the figure of

16 Podanie delegatury ukraińskiej ludnosći prawosławnej z Wołynia d-ra Arsenjusza Reczyńskiego, Platona Domanieckiego, Eugenjusza Petrykowskiego do pana Ministra spraw wewnętrznych 25 grudnia 1926 r Volyn State Archive, Fond 46, List 9, File $699, P .4$

17 Pismo Ministerstwa wyznań religijnych i oświecenia publicznego Ministerstwu spraw wewnętrznych, № VI. II/10629/26, 18 stycznia 1927 r. Volyn State Archive, Fond 46, List 9, File 699, P. 4. 18 Лист архімандрита Полікарпа (Сікорського) Петру Певному, 24 березня 1927 р. Державний архів Волинської області (Archimandrite Polikarp (Sikorskiy's) Letter to Petro Pevnyi, March 24 ${ }^{\text {th }}$ 1927. Volyn State Archive, Fond 199, List 2, File 1, P. 68).
Archimandrite Polikarp was removed for several years from the agenda of changes. It was not until the early 1930s that Father Poliakrp returned to active Ukrainian church life.

In the second half of 1928, a series of changes in the political life of the Volyn Voivodeship testified to a new stage in Polish-Ukrainian relations, which, among other things, affected the matter of Orthodoxy and eventually led to the consecration of Archimandrite Polycarp (Sikorski) into bishops. At that time, the newspaper Ukrainska Nyva was removed to Lutsk from Warsaw. The editor and publisher of this magazine was a former UPR member, Petro Pevnyi. $\mathrm{He}$ also led a group of Volyn opportunists.

In April of 1929, in the Volyn Voivodeship, the first Own Home ${ }^{19}$ club in Lutsk was established. At the same time, the press spoke of an attempt by the Ukrainian Orthodoxy to resume Lutsk's Holy Cross Fraternity ${ }^{20}$. Already in the late 1920s, the idea of updating the charter of the fraternity and giving the institution a new life emerged among the opportunists. Lutsk Holy Cross Fraternity was a symbolic organization within the framework of Polish-Ukrainian cooperation since it was founded and operated in the $17^{\text {th }}$ century. within that time's Polish legislation.

The parliamentary elections in Poland of 1930 were also a success for the Volyn opportunists. A group of ambassadors and senators, led by Petro Pevnyi, won many parliamentary seats. Ambassadors and senators, besides P. Pevnyi, became E. Boguslavsky, S. Skrypnyk, M. Maslov, S. Tymoshenko and others.

In addition to strengthening Petro's group, there was an unsuccessful attempt on the part of Metropolitan Dionysii to convene the Local Council, based on the proMoscow Orthodox clergy of the Orthodox Church of Poland, to which Warsaw was officially opposed. This shook the pendulum of affection towards the Ukrainians. Therefore, at the beginning of 1930, the Ministry of Religions and People's Education stated that it was not necessary to meet the wishes of the Orthodox citizens of Volyn and to appoint a separate leader of the Volyn-Kremenets Diocese. The Russians asserted that this was pressure on the head of the Church ${ }^{21}$. In any case, Archimandrite Polikarp (Sikorskyi) was again mentioned as the first and most likely contender for episcopal consecration.

In February of 1931, Volyn ambassadors P. Pevnyi and E. Boguslavsky spoke from the Sejm tribune about the problems of the development of the Orthodox Church in Poland. They were the first to assert the need for the convening of the Local Council, thus robbing Metropolitan Dionysii of his initiative and the Orthodox Episcopate. Yevhen Bohuslavskyi's speech made the demand for the de-Russification of the Church clear, as well as for the restoration of Ukrainian church traditions and the consecration of a Ukrainian into a bishop. It was a clear signal to the Russian hierarchy about the seriousness of the demands of the Ukrainian national-church movement and the need to fulfill them.

In that situation, Metropolitan Dionysii tried to outstrip his opponents. In August, the Novy Chas newspaper wrote about the likelihood of Archimandrite Savva (Sovetov) being consecrated to the bishop of Volyn. Oleksii (the Public)

\footnotetext{
${ }^{19}$ Otwarcie "Ridnoj Chaty". Przegląd Wołyński. 1929. № 18 (253). 28 kwietnia. S. 3.

20 Komunikat Tymczasowego Zarządu Łuckiego bractwa Podniesienia Św. Krzyza. Przegląd Wołyński. 1929. № 18 (253). 28 kwietnia. S. 2.

${ }^{21}$ Vox. From the print. Stabilization. Sunday reading. 1930. No 5. February 02. pages 78-80.
} 
was to lead the Diocese of Vilnius, and he planned to move Simon (Ivanovskyi) to Grodno. These intentions of Metropolitan Dionysii, as noted in the press, were crossed out by the governor G. Yuzevsky. The bidding of Metropolitan Dionysii with power lasted for another six months. In the end, official Warsaw agreed to the consecration of Savva (Sovetov), but under the circumstances of the ordination of Polikarp (Sikorski) to the Vicar Bishop of Lutsk.

During 1922-1932, Polikarp (Sikorskyi) was one of the main initiators of the Ukrainianization of the Orthodox Church in Volyn and the leader of the movement for the religious and national independence of Ukraine. His activities in the Dermansky, Miletsky, and Zagayat monasteries led to the Ukrainianization of his missions there, the improvement of the spiritual and moral atmosphere, the adjustment of the economic life of the monastic communities, and the formation of Ukrainian monasticism. In 1923, under the chairmanship of Archimandrite Polikarp (Sikorskyi), the Volyn Diocesan Assembly of the clergy and laymen made important decisions that supported the deRussification of the spiritual education of the region.

It was the very clear Ukrainian position of Archimandrite Polikarp that led to his removal from Volhynia late in 1923. Nevertheless, he maintained a close personal connection with like-minded people in Volyn. The authority of P. Sikorskyi among Orthodox Ukrainians urged the highest ecclesiastical authority to appoint him in 1926 to the post of a rector of the cathedral in Volodymyr.

\section{Conclusions}

Thus, the significant contribution to the Ukrainianization of the Orthodox Church in Poland, the leadership positions of Polycarp (Sikorski) in the movement for the religious and national independence of Ukraine ultimately led to the decision to ordain him to bishops, which significantly improved the position of Orthodox Ukrainians.

During the 1920s P. Sikorskyi became one of the leaders of the Ukrainian national-church movement Volhynia as a member of the clergy. Thanks to his activities, an attempt was made to Ukrainianise the dispatches in Dermansky, Miletsky and Zagayatsky monasteries. A special role was played by Archimandrite Polikarp, as rector of the Volodymyr cathedral parish, in the de-Russification of the dispatches, the establishment of the parish community in Volodymyr. The determination, perseverance and consistency in the struggle for the rights of Orthodox Ukrainians made Archimandrite Polikarp a symbolic figure of Ukrainian Orthodoxy in the region. His name was among the first in the list of potential candidates for bishops.

The role of Archimandrite Polikarp (Sikorskyi) in the development of the Volyn monasticism during his duties as a Dean of the monasteries of the Volyn Diocese and the use of Ukrainian-speaking liturgical texts in parish activities merits further study.

\section{REFERENCES}

Bidnov, V. (1921). Tserkovna sprava v Ukrayini. Terniv: Autcephalous Church of Ukraine Edition, 47 p. (In Ukrainian)

Berkhof, K. (2005). Chy bulo relihiyne vidrodzhennya v Ukrayini pid chas natsystskoyi okupatsiyi. Ukrainian Historical Journal. No. 3 (March): 16-36. (In Ukrainian)

Bartholomew (Vaschuk), Archbishop. (2003). Myletskyy SvyatoMykolayivskyy monastyr. Istoryko-krayeznavchyy narys. Rivne. 148 p. (In Ukrainian)

Vlasovsky, I. (1961). Narys istoriyi Ukrayinskoyi pravoslavnoyi tserkvy. New York-Bound Brook: The UOC in the United States, Vol. 4, issue 1. 384 p. (In Ukrainian)

Vlasovsky, I. (1977). Narys istoriyi Ukrayinskoyi pravoslavnoyi tserkvy. New York-Bound Brook: The UOC in the United States, Vol. 3. 390 p. (In Ukrainian)

Voloshin, Y. (1997). Ukrayinska pravoslavna tserkva $v$ roky natsystskoyi okupatsiyi (1941-1944). Poltava, 127 p. (In Ukrainian)

Doroshenko, D. (1940). Pravoslavna tserkva v mynulomu y suchasnomu zhytti ukrayinskoho narodu. Berlin: A Nation on the Move, 70 p. (In Ukrainian)

Pashchenko, V. (1997). Pravoslavya $v$ novitniy istoriyi Ukrayiny. Poltava: s.-h., Part 1. 356 p. (In Ukrainian)

Ranevsky, S. (1948). Ukrainian Autocephalous Church. Jordanville: Printing House of the Monk Job of Pochaiiv, the Holy Trinity Monastery, 22 p. (In Russian)

Savchuk, S., Mulyk-Lutsyk, Y. (1984). Istoriya Ukrayinskoyi hrekopravoslavnoyi tserkvy $\vee$ Kanadi. $U$ 4-kh $t$. Winnipeg: The Ecclesia Publishing Union, 1984. Volume One: The Kyiv Tradition of Canadian Ukrainians. 616 p. (In Ukrainian)

Stokolos, N. (2003). Konfesiyno-etnichni transformatsiyi v Ukrayini (XIX - persha polovyna XX st.). Rivne: Lista, 480 p. (In Ukrainian)

Ukrainizatsiya Vladimir-Volynskogo sobora (1927). The Light of Truth. No. 1. May 15. 20 p. (In Russian)

Tserkovne zhyttya. Posvyachennya ukrayinskoyi tserkvy $v$ Volodymyri (1927). The People's Bulletin. Vol. 30. November $10^{\text {th }}$. P. 6. (In Ukrainian)

Shkarovsky, M. (2007). Krest i svastika. Natsistskaya Germaniya i Pravoslavnaya Tserkov. Moscow: Veche, 512 p. (In Russian)

Heyer, F. (1953). Die Orthodoxe Kirche in der Ukraine von 1917 bis 1945. Köln-Braunsfeld: Verlagsgesellschaft Rudolf Muller, 1953. 271 s. (In Deutch)

\section{LIST OF REFERENCES LINKS}

Біднов В. Церковна справа в Україні. Тернів: Видання Українська автокефральна церква, 1921. 47 с.

Беркгоф К. Чи було релігійне відродження в Україні під час нацистської окупації. Український історичний журнал. 2005. № 3. березень. С. 16-36.

Варфоломій (Ващук), архієпископ. Милецький Свято-Миколаївський монастир. Історико-краєзнавчий нарис. Рівне, 2003. 148 c.

Власовський І. Нарис історії Української православної церкви. Нью Йорк-Бавнд Брук: УПЦ в США, 1961. Т. 4, кн. 1. $384 \mathrm{c}$.

Власовський І. Нарис історії Української православної церкви. Нью Йорк-Бавнд Брук: УПЦ в США, 1977. Т. З. 390 с.

Волошин Ю. Українська православна церква в роки нацистської окупації (1941-1944рр.). Полтава, 1997. 127 с.

Дорошенко Д. Православна церква в минулому й сучасному житті українського народу. Берлін: Нація в поході, 1940. $70 \mathrm{c}$.

Пащенко В. Православ'я в новітній історії України. Полтава: б.в., 1997. Ч. 1. 356 с.

Раневский С. Украинская автокефальная церковь. Джорданвиль: Типография преподобного Иова Почаевского в Св.Троицком монастыре, 1948. 22 с.

Савчук С., Мулик-Луцик Ю. Історія Української греко-православної церкви в Канаді. У 4-х т. Вінніпег: Накладом видавничої спілки "Екклезія", 1984. Том перший: Київська традиція українців Канади. 616 с.

Стоколос Н. Конфесійно-етнічні трансформації в Україні (XIX перша половина XX ст.). Рівне: Ліста, 2003. 480 с.

Украинизация Владимир-Волынского собора. Свет истины. 1927. № 1. 15 мая. 20 с.

Церковне життя. Посвячення української церкви в Володимирі. Народній вісник. 1927. Ч. 30. 10 листопада. С. 6.

Шкаровский М. Крест и свастика. Нацистская Германия и Православная Церковь. Москва: Вече, 2007. 512 с.

Heyer F. Die Orthodoxe Kirche in der Ukraine von 1917 bis 1945. Köln-Braunsfeld: Verlagsgesellschaft Rudolf Muller, 1953. $271 \mathrm{~s}$. 
Ігор Скиба,

Волинська православна богословська академія (м. Луизьк, Україна)

e-mail: prorector@vpba.org,ORCID0000-0003-0331-184

\section{МІСЦЕ ТА РОЛЬ ПОЛІКАРПА (СІКОРСЬКОГО) В ПОШИРЕННІ ТА ЗМІЦНЕННІ РУХУ ЗА УКРАЇНІЗАЦІЮ ПРАВОСЛАВНОЇ ЦЕРКВИ В ПОЛЬЩІ У 20-Х рр. ХХ $\mathrm{cm}$.}

Динаміка змін у духовному й церковно-релігійному просторі України останніх чверть століття свідчать про виразну тенденцію до самовизначення й інституціонування православної спільноти. Одним із етапів руху за створення Української православної церкви стала перша половина XX ст. Особливе місце у згаданих подіяX займає постать митрополита Полікарпа (Сікорського). У 1922 р. колишній співробітник Київської духовної консисторії та Міністерства віросповідань Уряду Української Народної Республіки Петро Сікорський опиняється на Західній Волині, котра увійшла до складу Другої Речі Посполитої. Після постригу Полікарп (Сікорський) очолив Дерманський монастир, а невдовзі Милецьку обитель. У Милецькому монастирі ієромонах Полікарп використав усі можливості для українізації життя чернечої громади. На початку 1923 р. Полікарп (Сікорський) - благочинний монастирів Волинської єпархії. Важливою була для Полікарпа (Сікорського) участь у роботі Волинського єпархіального з'їзду 1923 р., де він головував. Рішення з'їзду дали формальну основу для українізації відправ. Делегати проголосували за повернення української мови в богослужіння, підготовку україномовних богослужбових текстів. У першій половині 1923 р. архімандрит Полікарп (Сікорський) вже настоятель Загаєцького чоловічого монастиря. Тут він серед іншого зосередився на дерусифікації відправ та усього ритму духовного життя братії. Польська поліція ретельно стежила за архімандритом і стверджувала, що Сікорський перетворив монастир на вогнище української агітації. Духовно-національна позиція архімандрита Полікарпа (Сікорського) турбувала не лише польську поліцію, але й російські церковно-політичні кола, У жовтні 1923 р. глава Церкви відповідним розпорядженням переводить П. Сікорського у Вільно. Посилення українського національно-церковного руху зумовили призначення архімандрита Полікарпа (Сікорського) настоятелем собору та благочинним міської округи у Володимир весною 1926 р. В цей час у місті загострюється конфлікт між промосковськими священиками та українською громадськістю на чолі із Арсеном Річинським. Полікарпу (Сікорському) вдалося задовольнити вимоги українців, однак на початку 1927 р. його переводять у Жировицький монастир. Незважаючи на це архімандрит Полікарп (Сікорський) залишався одним із лідерів і символічною особою в українському національно-церковному русі Волині. Це підтвердив також Луцький церковний з'їзд 1927 р. та інші події в житті Православної церкви в Польщі. Іншим напрямом контактів архімандрита Полікарпа залишався зв'язок із уенерівськими колами. Полікарп (Сікорський) підтримував діалог із лідером УНР в екзилі Андрієм Лівицьким. Усі ці обставини зумовили висвяту Полікарпа (Сікорського) на єпископа Луцького в 1932 р. У даній статті вперше оприлюднено невідомі й уточнено низку маловідомих біографічних моментів архієрея, проаналізовано його вплив на українізацію Церкви на Волині в міжвоєнний період. Мета дослідження полягає у тому, щоб дослідити масштаби українізаційної діяльності Полікарпа (Сікорського) на Волині та його вплив на суспільно-релігійні процеси. Основним результатом дослідження стало визначення внеску Полікарпа (Сікорського) в українізацію церковно-релігійного життя православних міжвоєнної Польщі та масштабу впливу постаті владики на здобутки національно-церковного руху Волині в міжвоєнний період.

Ключові слова: Українська православна церква; Полікарп (Сікорський); Волинсько-Кременецька єпархія; українське православ'я; українізація.

(C) Ihor Skyba

Надійшла до редакції: 05.11.2019

Прийнята до друку: 28.11.2019 